\title{
MAŁA I ŚREDNIA PRZEDSIĘBIORCZOŚĆ W KONCEPCJ ORDOLIBERALIZMU I LIBERALIZMU SPOŁECZNEGO
}

\section{W poszukiwaniu przyczyn trudności związanych z promocją małych i średnich przedsiębiorstw (MŚP)}

Zastanawiająca jest niewspółmierność znaczenia gospodarczo-społecznego MŚP do nikłej reprezentacji interesów środowiska przedsiębiorców prowadzących MŚP w sferze polityki i w życiu publicznym. Postawmy na początku pytanie: jak więc w przypadku MŚP sprawić, by głos przedsiębiorców został usłyszany? Nie chodzi przy tym tylko o poszukiwanie adekwatnych środków retorycznych czy formę promocji środowiska MŚP.

Na początku należy próbować naświetlić przyczyny nikłego istnienia w naszej świadomości problemów trapiących to środowisko. Jeśli się to uda, to poczynimy mały krok na drodze do przywrócenia znaczenia przedsiębiorcom prowadzącym MŚP.

Przyczyn nieliczenia się z ich opinią należy poszukiwać w istnieniu określonych barier w sferze mentalnej. Aby tę sytuację zmienić, potrzebne jest ich rozpoznanie i zdefiniowanie. W dalszej kolejności należy się zastanowić nad kwestią wyboru perspektywy światopoglądowej, w jakiej dojdzie do formułowania racji przedsiębiorców prowadzących MŚP przed ich prezentacją opinii publicznej i politykom. Włączenie się w skuteczny sposób w dyskurs publiczny zakłada zatem wypracowanie języka i aparatu pojęciowego oraz przemyślenie założeń, na których będą formułowane wypowiedzi na temat MŚP ${ }^{1}$.

\footnotetext{
${ }^{1}$ D. Harvey, zastanawiając się, dlaczego neoliberalizm tak skutecznie przemówił do rozumu i serca wielu ludzi, sformułował warunki zaistnienia wraz z sukcesem określonej argumentacji w sferze świadomości społecznej: „[...] aby jakiś nurt [...] stał się dominujący, trzeba do niego wypracować aparat pojęciowy, który przemawia do naszych intuicji i instynktów, do naszego systemu wartości i do naszych pragnień, a zarazem ma jakieś odniesienie do możliwości obecnych w społecznym uniwersum, które zamieszkujemy. Jeśli się to powiedzie, ów aparat pojęciowy zagnieżdża się tak głęboko w potocznym pojmowaniu świata, że traktuje się go jako oczywistość, jako coś, co nie podlega kwestii”. D. Harvey, Neoliberalizm. Historia katastrofy, Książka i Prasa, Warszawa 2008, s. 13.
} 
Zauważmy, że pragnąc jak najlepiej wyrazić głos przedsiębiorców prowadzących MŚP, jego rzecznicy spotykają się z niezrozumieniem, co prowadzi do nieskuteczności działań na rzecz promocji MŚP. Jedną z przyczyn jest stan świadomości adresatów tych przekazów. Powszechnie pokutuje w świadomości społecznej kilka schematów pojęciowych i założeń doktrynalnych uniemożliwiających w jakikolwiek sposób nie tylko przyjęcie, ale nawet zrozumienie argumentacji na rzecz MŚP. W filozofii wspomina się o szklanym suficie ideologii i uprzedzeń. Jest on niewidoczny, ale można się dotkliwie poturbować, uderzając o niego. Mówi się też, że „istnieje zmowa milczenia” i dlatego głos przedsiębiorców prowadzących MŚP nie może się przebić do opinii publicznej.

Sytuacja środowiska w okresie transformacji przypomina historię opisywaną w staroindyjskiej opowieści, w której papuga po wydostaniu się z klatki rozbiła się na pierwszej napotkanej szybie. Ten szklany sufit zbudowany przez ideologię i uprzedzenia nie tylko uniemożliwia zrozumienie przekazu formułowanego przez przedsiębiorców prowadzących MŚP, ale jednocześnie czyni bezowocnym dialog środowiska tych przedsiębiorców w ramach debat publicznych. Dlatego również warto, aby filozofia analizująca życie publiczne poszukała ukrytych założeń niewidocznych zarówno dla propagatorów racji MŚP, jak i dla opinii publicznej. Jest to tym bardziej konieczne, gdyż na szczeblu zarówno regionalnym, a mianowicie na szczeblu UE, jak i krajowym toczy się rywalizacja o fundusze oraz przywileje dla poszczególnych grup przedsiębiorstw gospodarek narodowych i właśnie w tej rywalizacji gremia dążące do marginalizacji krajowych i europejskich MŚP wykorzystują ideologię i uprzedzenia dotyczące tych przedsiębiorstw.

Istnieją trzy rodzaje dyskursu o gospodarce i społeczeństwie marginalizujące rolę MŚP: jeden oparty jest na interpretacji teorii ewolucji K. Darwina, drugi nawiązuje do doktryny rewolucji K. Marksa, a trzeci, najbardziej obecny w życiu publicznym, wykorzystuje doktrynę wolnego rynku głoszoną przez neoliberalizm.

\subsection{Popularna interpretacja teorii ewolucji K. Darwina}

Ulubionym zabiegiem mającym usprawiedliwić koncentrację kapitału czy też zwiększanie się liczby wielkich przedsiębiorstw przemysłowych i handlowych stanowi przyrównanie procesów gospodarczych do przyrodniczych. W obu przypadkach ma panować prawo silniejszego. Najsilniejszy zdolny jest opanować niszę ekologiczną zamieszkałą przez inne organizmy czy też, jak ma to miejsce w gospodarce, najsilniejsze podmioty mogą i powinny opanować znaczne obszary rynku. Twierdzi się, że działania z pozycji siły, często prowadzące do wyeliminowania mniejszych uczestników życia gospodarczego, są zgodne z prawami ewolucji, które naszkicował 
K. Darwin w swym dziele O powstawaniu gatunków droga naturalnego doboru, czyli o utrzymywaniu się doskonalszych ras w walce o byt.

Należy jednak zauważyć, że K. Darwin nie używa nigdzie kategorii siły, a doskonałość organizmów w walce o byt sprowadza się do zdolności adaptacji do zmieniających się warunków. Wynika $\mathrm{z}$ tego, że wielkość przedsiębiorstw wcale nie jest równoznaczna $z$ doskonalszymi zdolnościami adaptacyjnymi, a niekiedy wręcz przeciwnie - świadczy na ich niekorzyść 2 .

Tym samym załamuje się ulubiona teza głoszona przez zwolenników neoliberalizmu, która według nich miałaby świadczyć o realizmie i w ostateczności o konieczności przyjęcia doktryny neoliberalnej. Otóż owa teza sprowadza się do stwierdzenia, że w gospodarce rynkowej panują twarde prawa konkurencji tak jak w dżungli, gdzie każdy zjada każdego i wygrywa najsilniejszy (taki przynajmniej obraz dżungli wynika z powierzchownej jej obserwacji). Jeśli ta interpretacja byłaby prawdziwa, to nie pozostawałoby nam nic innego jak zgoda na marginalizację MŚP i monopolizację życia gospodarczego przez wielkie, transnarodowe korporacje. Także logiczną tego konsekwencją byłoby bezwarunkowe ich ratowanie, gdyż - jak to się powiada są za duże, by upaść (too big to fail).

Nie jest również prawdą, że ewolucja przebiega w kierunku większej złożoności. Jeśli prostsze organizmy zdolne są do adaptacji do zmieniających się warunków, to one przetrwają i w danym miejscu nie potrzebne jest ich zastąpienie przez bardziej złożone ${ }^{3}$. Ponadto $w$ ewolucji nie chodzi o to, by największe organizmy całkowicie opanowały dany teren, ale aby na danym terenie panowała różnorodność organizmów. Dzięki temu mogą one optymalnie wykorzystać istniejące warunki, a w trakcie zmian jest większa szansa na to, że któryś z nich przetrwa i da początek nowym gatunkom czy nawet rodzajom. W ostateczności cel ewolucji to trwanie w obliczu

2 Dla przykładu dinozaury, a przede wszystkim ich wielkość była przyczyną braku zdolności do adaptacji w nowych warunkach, dlatego stworzenia te wymarły. Wielkość wcale nie jest też preferowana w procesie ewolucji gospodarczej. Wykazał to dobitnie przykład amerykańskiego przemysłu samochodowego, w którym produkowano krążowniki szos, zużywające ogromne ilości paliwa. Nie potrafiono zaprzestać tej produkcji w dobie kryzysu paliwowego, co w końcu doprowadziło do bankructwa wiele koncernów samochodowych, a miasto Detroit do upadku.

3 „Karaluchy istnieją od setek milionów lat, przetrwały, gdy dżungle zamieniły się w pustynie, a pustynie przekształciły w miasta. Udało im się to dzięki prostemu, wręcz trywialnemu mechanizmowi obronnemu. Chroniąc się przed niebezpieczeństwem, karaluch nie posługuje się zmysłami wzroku, słuchu ani węchu. Po prostu zawsze przemieszcza się w przeciwnym kierunku niż podmuchy wiatru owiewające mu odnóża. W żadnym środowisku nie zdobyłby nagrody dla »najlepiej zaprojektowanego insekta«, ale zdołał przetrwać w każdym z nich. Inne owady mogą być lepiej przystosowane do poszukiwania pożywienia lub maskowania swojej obecności w danych warunkach, ale niewiele wykazuje się tak niezłomną wolą przetrwania w obliczu nieuchronnych zmian". R.M. Bookstaber, Jak stworzyliśmy demona. Rynki, fundusze hedgingowe i ryzyko innowacji finansowych, Kurhaus, Warszawa 2012, s. 13. 
zmian, czyli przetrwanie biomasy, a w niej genotypu, a nie ostateczne pokonanie innych żywych organizmów.

Z dotychczasowej analizy wynika zatem, że poszukiwanie analogii pomiędzy rozwojem przyrody a przemianami gospodarczymi w sferze podmiotów gospodarczych, $\mathrm{w}$ tym powoływanie się na autorytet K. Darwina i jego teorię ewolucji, powinno prowadzić do odmiennych wniosków niż stwierdzenie nieuchronności koncentracji kapitału i wzrostu, a w konsekwencji ostatecznej dominacji wielkich organizacji przemysłowych i handlowych.

Ewolucja bowiem zakłada i wręcz wspiera różnorodność gatunkową, organizmy zdolne do szybkiej adaptacji i prostsze organizacyjnie, jeśli to jest możliwe w danych warunkach. Co więcej, w wyniku gwałtownych zmian otoczenia organizmy żywe, które przetrwały, liczą co najwyżej 5 ton, gdy największe dinozaury, które wyginęły, miały wagę do 90 ton. Również nowy ekspansywny rodzaj, a mianowicie ptaki, zdolny do adaptacji w nowych warunkach, wyodrębnił się z grupy małych dinozaurów. Oczywiście, jeśli nasuwa się w tym wypadku jakaś analogia do sfery gospodarczej i jej rozwoju, to jest to fakt, że MŚP stanowią podstawę zdrowej gospodarki, a nie relikt przeszłości, który należy jedynie utrzymywać ze względu na wymogi społeczne. Szybko adaptują się do zmieniających się warunków gospodarczych w czasie transformacji w przeciwieństwie do dużych korporacji, które - choć niesprawne - nie mogą upaść (too big to fail) i dla których trzeba z konieczności organizować ogromne sumy przeznaczone na ich ratowanie.

Taka właściwa interpretacja ewolucji pozwoli zbić argument dotyczący naturalnego procesu eliminacji MŚP. Jednak jej przyjęcie rodzi również pewne zobowiązanie, a mianowicie określonego rozumienia, czym w ujęciu ewolucyjnym mają być MŚP, czyli - w którym kierunku ma zmierzać ich ewolucja. Otóż obecnie grupa przedsiębiorców prowadząca MŚP należy do najbardziej pesymistycznie nastawionej w stosunku do trendów rozwoju gospodarczego i polityki państwa. Wynika to przede wszystkim $\mathrm{z}$ funkcjonowania $\mathrm{w}$ ramach tego środowiska dużej liczby drobnych przedsiębiorców reprezentujących lokalny handel, upadający pod wpływem rozwoju sieci dyskontowej i wielkopowierzchniowej, czy też drobnych przedsiębiorców, niewytrzymujących również konkurencji firm zagranicznych.

Jeśli dobrze można wytyczyć kierunek dalszej ewolucji handlu, usług i przemysłu, to szanse na przetrwanie, rozwój i ekspansję będą miały tylko takie przedsiębiorstwa, które zaproponują radykalnie coś innego niż to, co oferują wielkie korporacje. Muszą to być produkty alternatywne względem np. konserwowanej żywności dostępnej w sieciach handlowych czy bardziej innowacyjne niż oferowane przez korporacje. W drodze ewolucji zatem powstaną nowe MŚP, zdolne do walki konkurencyjnej i do objęcia uznanego miejsca na mapie gospodarczej poszczególnych 
krajów. Na pewno nowych MŚP nie będą tworzyć drobni kupcy walczący o zablokowanie budowy wielkoformatowych sklepów w swojej okolicy ze względu na to, że sami sprzedają te same produkty, które w przyszłości zaoferują na tym miejscu hipermarkety i dyskonty.

\subsection{Cień doktryny rewolucji K. Marksa}

Doktryna rewolucji K. Marksa, choć nie ma już tylu zwolenników co dawniej, to jednak zakorzeniła się w świadomości. Kalki pojęciowe i schematy myślenia wpajane przez lata również powodują, że osoby propagujące MŚP spotykają się z niezrozumieniem czy wręcz traktowane są jako broniące złej sprawy.

Koncepcja rewolucji w dużym stopniu zdeterminowała spojrzenie K. Marksa na MŚP. Według niego postęp polega na tym, iż „nowoczesny przemysł przekształcił drobny warsztat patriarchalnego majstra w wielką fabrykę przemysłowego kapitalisty" ${ }^{\text {. W }}$ tym sformułowaniu najlepiej widać, że według K. Marksa i jego zwolenników nie ma się co liczyć z MŚP, a uwagę należy skierować na największe zakłady. Nie tylko wielkie zakłady przemysłowe mają być podstawą wprowadzenia postępu technicznego, ale również powstający w ich ramach nowy typ robotnika ma stworzyć szansę na realizację społecznej utopii komunistycznej.

K. Marks pisał, że wraz „Z rozwojem przemysłu proletariat nie tylko powiększa się liczebnie; jest on stłaczany w coraz większe masy, siła jego rośnie i coraz bardziej czuje on tę siłę"5. Tym samym wielkie zakłady przemysłowe przygotowują same swoją zgubę, gdyż - jak badał to K. Marks, a obserwował na własnym przykładzie F. Engels (posiadający zakład w Manchesterze) - „praca proletariuszy na skutek rozpowszechnienia maszyn i podziału pracy zatraciła wszelkie cechy samodzielności, a wraz z tym wszelki powab dla robotnika. Staje się on zwykłym dodatkiem do maszyny, wymaga się odeń tylko czynności najprostszych, najbardziej jednostajnych, do wyuczenia się najłatwiejszych. Koszt robotnika ogranicza się zatem niemal wyłącznie do środków żywności niezbędnych do jego utrzymania i zachowania jego gatunku"6.

Stosunek K. Marksa do wielkich zakładów przemysłowych był zresztą ambiwalentny. $Z$ jednej strony praca $w$ nich rodziła alienację, ale $\mathrm{z}$ drugiej strony to te zakłady przyczyniały się do niespotykanej $\mathrm{w}$ historii skali wprowadzania postępu technicznego. Nawet badacze niezgadzający się czy wręcz zwalczający koncepcję

\footnotetext{
${ }^{4}$ K. Marks, F. Engels, Dzieła, t. 4, Książka i Wiedza, Warszawa 1962, s. 7.

${ }^{5}$ Ibidem, s. 8.

6 Ibidem, s. 7.
} 
K. Marksa przejęli jego punkt widzenia, sprowadzający się do upatrywania w wielkich organizacjach gospodarczych podstawę rozwoju życia gospodarczego.

W tej perspektywie drobny przemysł, rzemiosło, małe i średnie zakłady traktowano jako anachronizm czy wręcz jako przeżytek feudalny, czyli cechowy sposób produkcji. Szczególnie w grupie decydentów istniała fascynacja rozwojem wielkiego przemysłu i wielkoprzemysłowej klasy robotniczej, traktowanej jako podstawa społeczna ustroju.

Doprowadziło to nie tylko do forsowania budowy wielkich, nierentownych zakładów przemysłu ciężkiego, nawet w granicach miast - jak miało to miejsce w Krakowie i Warszawie, ale również do rozpoczęcia bezwzględnej walki z MŚP. Dlatego też po okresie odbudowy, głównie dokonanej właśnie przez przedsiębiorców zakładających MŚP, wprowadzono w PRL-u reformy H. Minca, nazwane „bitwą o handel"7, oraz dekrety B. Bieruta dotyczące wywłaszczenia i upaństwowienia MŚP. Taka polityka gospodarcza wynika w sposób konsekwentny z przyjęcia stanowiska względem przedsiębiorców prowadzących MŚP zadeklarowanego już Manifeście komunistycznym. K. Marks wyraźnie wskazuje, że „stany średnie - drobny przemysłowiec, drobny kupiec, rzemieślnik, chłop - wszystkie one zwalczają burżuazję po to, by uchronić od zagłady swoje istnienie jako stanów średnich. Są one zatem nie rewolucyjne, lecz konserwatywne. Więcej nawet, są reakcyjne, usiłują bowiem obrócić wstecz koło historii"'.

Jak wynika więc z tej analizy, MŚP przez prawie półwiecze były postrzegane nie tylko jako anachronizm, odchodzący do przeszłości wraz z nowocześniejszymi formami organizacji gospodarczej, ale też przez marksistów jako groźne zjawisko z punktu widzenia polityki. MŚP bowiem miały przyczynić się do powstania grupy społecznej wrogiej przemianom ustrojowym.

Z proroczej wizji Manifestu komunistycznego niewiele na szczęście zostało zrealizowane. Jedynie to, i tego właśnie dotyczy „śmiech historii”, że proletariat stał się - jak pisał dosadnie K. Marks - grabarzem; jedno, czego nie przewidział, to tego, że stał się grabarzem ustroju powołującego się na jego właśnie pisma. Samo więc życie zaprzeczyło próbom marginalizacji MŚP. Przetrwały one wrogi dla siebie okres PRL-u, a pierwsze radykalne reformy rządu na wpół jeszcze komunistycznego oparte były na projekcie M. Wilczaka, reprezentanta przedsiębiorców prowadzących MŚP. Natomiast wielkie przedsiębiorstwa stworzone w czasach PRL-u w dużej liczbie nie

\footnotetext{
7 Była ona wypełnieniem złowrogiej deklaracji: „Gadanina o wolnym handlu, podobnie jak wszystkie inne tyrady wolnościowe naszej burżuazji, ma w ogóle jakiś sens tylko w stosunku do handlu skrępowanego, w stosunku do ujarzmionego mieszczanina średniowiecza, lecz nie w stosunku do komunistycznego zniesienia handlu, zniesienia burżuazyjnych stosunków produkcji i samej burżuazji”. Ibidem, s. 11.

8 Ibidem, s. 9.
} 
przetrwały radykalnej zmiany otoczenia gospodarczego. Na ich gruzach, często też przy wykorzystaniu ich majątku, know-how i sieci powiązań kooperacyjnych oraz list klientów, powstały MPŚ radzące sobie na wolnym rynku ze zmiennym szczęściem. W tym sensie również rzetelna analiza doktryny marksistowskiej, doktryny materializmu historycznego ukazuje błędność proroctw K. Marksa co do losu MŚP.

\subsection{Neoliberalizm i jego doktryna wolnego rynku a próby marginalizacji roli MŚP}

Neoliberalizm stanowi podstawę trzeciego rodzaju dyskursu mającego wpływ na postrzeganie i możliwości rozwoju MŚP. To, co uważa się za doktrynę neoliberalizmu, mało ma wspólnego z poglądami M. Friedmanna, a już na pewno A. Smitha i F.A. von Hayeka. Jednak ich wypowiedzi stworzyły pole do szczególnie popularnej interpretacji istoty kapitalizmu, a właściwie gospodarki rynkowej, ponieważ neoliberalizm stara się unikać tego terminu, jako że kieruje on uwagę nie tylko na sukcesy gospodarcze, ale i na kondycję społeczeństwa.

W swej doktrynalnej wersji zwolennicy neoliberalizmu często przywołują na poparcie swojego fundamentalizmu rynkowego wyrwane z kontekstu dwie metafory pochodzące z tekstów A. Smitha. Pierwsza dotyczy „niewidzialnej ręki rynku”, a druga „państwa jako stróża nocnego". Mają one być podstawą uprawomocnienia poglądu, iż wolny rynek sam z siebie nie tylko dokona najefektywniejszego wytwarzania i alokacji dóbr, ale też pozwoli wszystkim znajdującym się na nim podmiotom na nieskrępowaną, wolną działalność w ramach walki konkurencyjnej.

Powołując się selektywnie na wypowiedzi F.A. von Hayeka z późnego okresu twórczości, można stwierdzić, że wolny rynek ma stanowić samoorganizujący się ład, który zapewnia przestrzeń do działania dla wszystkich. Jeśli dochodzi na nim do osiągania niesprawiedliwych w poczuciu indywidualnym korzyści, to wynikają one z logiki gry rynkowej i należy na nie przystać, gdyż jedynym oceniającym jest sam rynek, a wszelkie strategie polityki gospodarczej proponowane przez zwolenników aktywnej roli państwa w gospodarce rynkowej mają w ostateczności prowadzić do zaburzenia działania mechanizmu rynkowego.

Co ciekawe, w imię ochrony „wolnego" rynku zwolennicy neoliberalizmu w sytuacji, w której rynek ma wymierzyć sprawiedliwość największym - jak to się mówi w neoliberalizmie - „graczom na rynku”, dopuszczają pomoc państwa, owego według ich słów „stróża nocnego”, czyli kogoś, kto nie powinien posiadać dużych możliwości udzielania pożyczek.

Neoliberalizm głosi, że na poziomie systemowym możemy mówić o wolności, którą zresztą wyraża sformułowanie „wolny rynek”, natomiast na poziomie 
indywidualnych decyzji przedsiębiorcy nie pozostaje nic innego, jak bezwzględnie dostosować się do działania determinizmów wynikających z logiki praw rynkowych. Silna wiara w mechanizmy rynkowe, których działanie ma zapewnić bogactwo, prowadziła zwolenników neoliberalizmu do zajęcia stanowiska określonego mianem "fundamentalizmu rynkowego".

J.E. Stiglitz - najpierw zwolennik, a potem krytyk neoliberalizmu - twierdzi, że jest on ideologią wielkich przedsiębiorstw. „W wersji neoliberalnej łączy się leseferyzm z silnym rządem i z przywilejami korporacyjnymi. Nazywam to neoliberalizmem specjalnych interesów"10. To jego język, aparat pojęciowy i wnioski, które w jego ramach się formułuje, tworzą światopogląd broniący niekorzystnych trendów rynkowych przyczyniających się do eliminacji MŚP.

\section{Początki badań nad MŚP - niemiecka szkoła historyczna}

$\mathrm{Na}$ początku niniejszego artykułu zapowiedziano, że po odkryciu barier dalszym krokiem będzie poszukiwanie teorii i doktryn, dzięki którym dyskurs o MŚP ukaże swe znaczenie i umożliwi ich równouprawniony rozwój w organizmie gospodarczym.

Nadzieje takie stwarza analiza dorobku niemieckiej szkoły historycznej. Badania G. Schmollera realizowane w XIX w. ukazują możliwość prowadzenia rozważań o miejscu i roli małych i średnich zakładów z perspektywy ekonomiczno-społecznej oraz umożliwiają dostrzeżenie ich problemów w perspektywie politycznej określonej przez konserwatywny nurt zwanym socjalizmem ex cathedra. Cenne również było spojrzenie G. Schmollera na gospodarkę i społeczeństwo jako na organizm i układ organiczny, w którym małe i średnie przedsiębiorstwa pełnią określoną, nieredukowalną rolę. Niemiecka szkoła historyczna nie porzuciła ujęcia organicznego sięgającego tradycji metafizyki Arystotelesa. Występuje ono w opozycji do mechanicznego ujęcia Newtonowskiego. Społeczeństwo to organizm, w którym gospodarka stanowi jeden z układów zapewniających jego „zdrowie”. Dlatego wiedza o układzie, jakim jest gospodarka, wiąże się z ukazaniem związków pomiędzy częściami organizmu

\footnotetext{
${ }^{9}$ Od lat toczy się dyskusja na temat tego, czy w skali makro reformy w duchu neoliberalnym miały pozytywny wpływ na gospodarkę, czy też przeciwnie - przyczyniły się najpierw do dominacji giełdy nad bankami i gospodarką, następnie do megarozrostu świata finansów, co miałoby spowodować rozległy kryzys 2008+ w sferze bankowości, gospodarki i finansów państwowych.

10 A. Szahaj, Neoliberalizm to religia, rozmawiał A. Domosławski, „Gazeta Wyborcza” 20 stycznia 2007, http://wyborcza.pl/1,76498,3862752.html\#ixzz311EQRVJ3.
} 
społecznego, których nie można w pełni scharakteryzować na podstawie mechanistycznego modelu badanie relacji. W ujęciu organicznym MŚP wypełniają swoją rolę jako jeden $\mathrm{z}$ „organów” gospodarstwa społecznego. W tej perspektywie niemiecka szkoła historyczna tworzyła ekonomiczno-społeczne analizy sytuacji w dobie industrializacji małych i średnich zakładów o niskim stopniu umaszynowienia.

Otóż kiedy K. Marks zapoznawał się w bibliotece British Museum z danymi opisującymi fenomen manchesterskiego kapitalizmu, przedstawiciel młodszej szkoły historycznej G. Schmoller podjął się badań małych zakładów na terenie Prus. W 1870 r. w Halle publikuje Zur Geschichte der deutschen Kleingewerbe im 19. Jahrhundert, w którym ukazuje, iż wkraczanie form kapitalizmu manchesterskiego jest wspierane hasłami leseferyzmu gospodarczego (podobnie jak będzie to miało miejsce później za czasów R. Reagana i M. Thatcher), prowadzi do rozwoju gospodarczego, a w ostateczności do napięć społecznych spowodowanych wypieraniem przez manchesterski kapitalizm tradycyjnych form gospodarowania. Jako reprezentant konserwatystów, G. Schmoller upatrywał w rozwoju unowocześnionych MŚP element stabilizacji organizmu społecznego. Próbował on też stworzyć nową alternatywę dla leseferyzmu gospodarczego, ukazując rolę państwa jako dostrzegającego problemy społeczne w szerszej perspektywie, niż czynią to inwestujący kapitaliści. Ich rozwiązanie staje się kluczem do zachowania wolności, również w sferze gospodarczej. Najważniejsze w analizie G. Schmollera wydaje się ukazanie znaczenia MŚP w perspektywie społeczno-ekonomicznej, oczywiście tak jak on ją rozumiał, czyli w ramach przyjętej przez niego kontrowersyjnej ideologii.

\section{MŚP z perspektywy ordoliberalizmu}

Tradycja polityczna, w ramach której w pełni ukaże się istota, rola i znaczenie MŚP, to niemiecki nowy liberalizm, starający się przebudować swoją doktrynę po Wielkim Kryzysie. Dostarczył on nowoczesnej perspektywy stanowiącej podstawę owocnego dyskursu o MŚP.

Zbadajmy zatem możliwości, jakie daje XX-wieczna próba odnowy doktryny liberalizmu. W polu zainteresowania ze względu na MŚP znajdzie się liberalizm społeczny, a właściwie dwie jego odmiany. Jedną jego postać rozwija się w ramach niemieckiego ordoliberalizmu. Dlatego też w ramach rozważań o możliwościach ujęcia istoty i roli MŚP przedstawimy koncepcję A. Rüstowa, odwołując się do ordoekonomii W. Euckena. Następnie przedstawimy zupełnie zapomnianą polską, przedwojenną koncepcję liberalizmu społecznego autorstwa F. Zweiga. 
Wymienieni myśliciele dokonują liberalnej krytyki doktryny leseferyzmu i neoliberalnej ideologii wolnego rynku. Odzyskanie języka dla przedstawienia problemów nękających przedsiębiorców prowadzących MŚP dokonuje się w liberalizmie społecznym przez wprowadzenie kategorii wolnej konkurencji na miejsce kategorii wolnego rynku.

Badając przyczyny kryzysu gospodarczego z 1933 r., młodzi liberałowie lat 30. XX w. doszli do wniosku, że polityka laissez faire jest nie do utrzymania jako składnik doktryny liberalnej. Dlatego w Paryżu w 1938 r. liberałowie zorganizowali dla wypracowania nowych form liberalizmu spotkanie, które przeszło do historii pod nazwą kolokwium Lippmanna ${ }^{11}$. W. Lippman wydał bowiem w 1937 r. ważną dla liberalizmu książkę Good Society. Sprzeciwiał się on „bezwarunkowemu, przesadnemu i dogmatycznemu stosowaniu zasad liberalizmu gospodarczego" ${ }^{12}$. Znaczna redukcja roli państwa, brak polityki gospodarczej i minimalizacja działań z zakresu polityki publicznej były według niego nie do utrzymania, jeśli nie chce się popaść w kolejny kryzys gospodarczy. Hasła skrajnego liberalizmu gospodarczego są według Lippmana tylko wtedy uzasadnione, gdy istnieje niebezpieczeństwo zbytniego rozrostu państwa i jego kontroli nad gospodarką. Jednak gdy to niebezpieczeństwo zostaje pokonane dzięki zwycięstwu partii liberalnych, to powinno chodzić według niego jedynie o ustalenie właściwej roli państwa w gospodarce.

W tym duchu rozwijał się ordoliberalizm. W. Eucken stworzył następnie podstawy do nowej polityki gospodarczej liberalizmu, w tym do nowego określenia relacji państwo-rynek i społeczeństwo-przedsiębiorstwa kapitalistyczne. W tych obszarach ujawnia się nowe spojrzenie na rolę i znaczenie MŚP, szczególnie w kontekście roli państwa i jej wpływu na gospodarkę.

Twórca ordoekonomii, W. Eucken, był zwolennikiem ustalenia reguł, według których toczy się gra rynkowa, tak by wszystkie podmioty miały szansę na konkurowanie w ramach tej gospodarki rynkowej. Ustrój gospodarczy, określając zespół reguł, wyznacza przestrzeń, w której możliwe są takie, a nie inne działania przedsiębiorców. Według W. Euckena chodzi o to, by w ramach gospodarczej działalności były możliwe tylko te działania, które są zgodne z normami moralnymi, a działania je naruszające były nieopłacalne. Stworzenie takiego ustroju gospodarczego umożliwia wszystkim podmiotom stanięcie do walki fair play.

Tak rozumiał W. Eucken, jako liberał, wypełnienie zasady wolności - podstawowej wartości dla liberalizmu. Twierdził, że dobrze wyznaczone reguły gry rynkowej są najlepszą strategią polityki społecznej, gdyż generują bogactwo, możliwie równomiernie

${ }_{11}$ Zob. H. Wünsche, Kapitalizm i społeczna gospodarka rynkowa: dwie sprzeczne koncepcje, „Zeszyt Naukowy" PTE 2002, nr 4, www.pte.pl/pliki/2/12/H.\%20Wunsche.pdf.

12 Ibidem, s. 12. 
je rozprowadzając, i najlepiej wytwarzają popyt konsumpcyjny. W swoich pracach W. Eucken wyznaczył zasady polityki gospodarczej przyjazne dla MŚP ${ }^{13}$.

Tabela 1. Zasady polityki gospodarczej według W. Euckena

\begin{tabular}{|c|c|c|}
\hline Zasady ogólne & Zasady konstytuujące & Zasady regulujące \\
\hline $\begin{array}{l}\text { Wolność, w tym wolność } \\
\text { gospodarcza, jest najwyższą } \\
\text { wartością. }\end{array}$ & $\begin{array}{l}\text { Primat der Währungspolitik: } \\
\text { - stabilizacja wartości pieniądza, } \\
\text { - stabilność walutowa, } \\
\text { - działania antyinflacyjne państwa. }\end{array}$ & $\begin{array}{l}\text { Ochrona konkurencji jako odpowiedź } \\
\text { na koncentrację władzy gospodarczej. }\end{array}$ \\
\hline $\begin{array}{l}\text { Wolności gospodarczej należy } \\
\text { aktywnie strzec, nie licząc tylko na } \\
\text { zachowanie jej na wolnym rynku. }\end{array}$ & $\begin{array}{l}\text { Funktionsfähiges Preissystem: } \\
\text { - funkcjonalny system cen (wskaźnik } \\
\text { rzadkości dóbr i zasobów) oparty na } \\
\text { działaniu wolnej konkurencji, } \\
\text { - zwalczanie dumpingu. }\end{array}$ & Regulacje płacowe. \\
\hline $\begin{array}{l}\text { Celem gospodarki jest pomyślność } \\
\text { wszystkich podmiotów } \\
\text { gospodarczych i konsumentów. } \\
\text { Najlepiej zapewnia się ją przez } \\
\text { wprowadzane przez państwo zasady } \\
\text { ładu konkurencyjnego. }\end{array}$ & $\begin{array}{l}\text { Offene Märkte: } \\
\text { - otwartość rynku, } \\
\text { - państwo dba o to, by nie było barier } \\
\text { na wejściu do niego, } \\
\text { - polityka antymonopolowa. }\end{array}$ & \\
\hline \multirow[t]{4}{*}{$\begin{array}{l}\text { Rynek krajowy jest otwarty na } \\
\text { konkurencję z zewnątrz. }\end{array}$} & $\begin{array}{l}\text { Privateigentum: } \\
\text { - konstytucyjne, prawne } \\
\text { i instytucjonalne zabezpieczenie } \\
\text { własności prywatnej, } \\
\text { - zmiany struktury własności jedynie } \\
\text { przez pośrednie działania państwa, } \\
\text { np. określenie wysokości podatku } \\
\text { spadkowego, } \\
\text { - dostępność dla wszystkich cen } \\
\text { rejestracyjnych. }\end{array}$ & \\
\hline & $\begin{array}{l}\text { Vertragsfreiheit: } \\
\text { wolność zawierania kontraktów } \\
\text { ograniczona jedynie przez regulacje } \\
\text { płacowe przy anomaliach rynku pracy. }\end{array}$ & \\
\hline & $\begin{array}{l}\text { Haftung: } \\
\text { - odpowiedzialność, } \\
\text { - podmioty gospodarcze są } \\
\text { pociągnięte do odpowiedzialności } \\
\text { za swoją działalność. }\end{array}$ & $\begin{array}{l}\text { Zewnętrzne efekty podlegają } \\
\text { internalizacji. }\end{array}$ \\
\hline & $\begin{array}{l}\text { Konstanz der Wirtschaftspolitik: } \\
\text { trwałość reguł w polityce } \\
\text { gospodarczej - dynamiczne procesy } \\
\text { gospodarcze nie powinny przyczyniać } \\
\text { się do gwałtownych zmian polityki } \\
\text { gospodarczej ze względów } \\
\text { politycznych czy koniunkturalnych. }\end{array}$ & \\
\hline
\end{tabular}

Źródło: opracowanie własne na podstawie literatury przedmiotu.

13 Rozszerzone opracowanie tabeli w: M. Moszyński, Zasady liberalnego ładu gospodarczego. Uniwersalizm czy specyficzność, IX Kongres Ekonomistów Polskich, s. 5, www.pte.pl/.../Moszyński\%20Michał/ Moszyński\%20Michał\%20-\%20ZAS. 
Z kolei F.A. von Hayek sformułował wobec tych reguł wymogi, które mógłby zaakceptować także W. Eucken. Są to następujące fundamentalne wskazówki:

- Reguły te powinny dotyczyć bez wyjątku wszystkich aktywnych w gospodarce podmiotów decyzji, mieć ogólny charakter i nie być ukierunkowane na żaden inny cel, jak tylko zapewnienie sprawnego funkcjonowania i stabilizacji istniejącego rynkowego ładu gospodarczego.

- Reguły te powinny być sformułowane generalnie w sposób negatywny, tj. zabraniający określonych decyzji i działań, ale nienakazujący żadnych innych decyzji i działań. Pryncypialną zasadą liberalizmu jest bowiem to, że to, co nie jest explicite zabronione, jest tym samym dozwolone.

- Podmioty decyzji gospodarczych powinny mieć pewność co do tego, że nieprzestrzeganie obowiązujących reguł gry pociąga za sobą niemożliwe do uniknięcia ściśle określone negatywne konsekwencje.

- Według teorii ładu gospodarczego, w ramach stwarzanych przez istniejące reguły gry interakcje pomiędzy podmiotami rynkowymi powinny przebiegać całkowicie swobodnie ${ }^{14}$.

Mając za wytyczne zasady ustrojowe i regulacyjne W. Euckena i reguły F.A. von Hayeka, można pokusić się o skonstruowanie przyjaznego ustroju gospodarczego dla MŚP i sformułowanie strategii polityki gospodarczej zapewniającej przyszłość ich rozwoju.

W. Röpke, kolejny nowy liberał próbujący odnowić problematykę liberalizmu, w 1948 r. napisał w pierwszym numerze wydawanego przez W. Euckena miesięcznika ordoliberałów „Ordo” artykuł Małe i średnie zakłady w gospodarce narodowej. Od tego czasu MŚP są traktowane w Niemczech jako zespół przedsiębiorstw konkurencyjnych, stabilizujących zatrudnienie, gdyż są mniej wrażliwe na cykle koniunkturalne.

${ }^{14}$ F.A. von Hayek, Grundsätze einer liberalen Gesellschaftsordnung, Mohr Siebeck, Tübingen 2002, s. 74-79, cyt. za: P. Pysz, Neoliberalizm/keynesizm versus ordoliberalizm a światowy ład gospodarczy, referat wygłoszony na konferencji PAN-RAS, Moskwa, 25-30.06.2012, s. 19, www.pte.pl/pliki/2/12/Piotr\%20 Pysz\%20referat\%20Moskwa.pdf. Tego samego autora także: Rechtsordnung und Handelnsordnung. Aufsätze zur Ordnungsökonomik, J.C.B. Mohr (Paul Siebeck), Tübingen 2003, s. 74-91. 


\section{Problematyka MŚP w ujęciu niemieckiego liberalizmu społecznego A. Rüstowa}

W opublikowanej w 1949 r. Religii gospodarki rynkowej (Die Religion der Marktwirtschaf) podniesiono kwestię znaczenia MŚP dla gospodarki i określono warunki ich rozwoju w gospodarce rynkowej po II wojnie światowej.

Liberalizm społeczny w ujęciu A. Rüstowa opowiada się za polityką życia (Vitalpolitik). Jej celem jest to, by gospodarka tworzyła i realizowała szanse życiowe wszystkich członków społeczeństwa. Pod tym kątem oceniany jest rozwój gospodarczy, struktura gospodarki i polityka państwa. W przeświadczeniu A. Rüstowa tylko ustrój gospodarczy zapewniający działanie wolnej konkurencji przyniesie dobrobyt i da szansę na rozwój MŚP. A. Rüstow był - jak wszyscy ordoliberałowie - świadomy tego, że jedynie wówczas, gdy w gospodarce rynkowej funkcjonuje zasada wolnej konkurencji, przedsiębiorcy działają w interesie klientów. Dlatego głównym problemem staje się dla niego nie tyle rozrost władzy państwowej nad gospodarką, ile rozrost prywatnej władzy gospodarczej - władzy wielkich przedsiębiorstw. Z tego też powodu przeciwstawia się gospodarce typu laissez faire, w której wolność nieujęta $\mathrm{w}$ ramy ustroju gospodarczego zostaje wykorzystana do eliminacji wolnej konkurencji. Powstały na gruncie leseferyzmu odłam liberalizmu A. Rüstow nazywa manchesterskim liberalizmem ${ }^{15}$. Walczy on ze szkodliwym według niego poglądem leseferyzmu redukującym rolę państwa do stróża nocnego i powierzającym los społeczeństwa działaniu niewidzialnej ręki rynku, a tak naprawdę działaniu monopoli, trustów czy współczesnych globalnych korporacji. Dlatego też przedstawiciele wielkiego kapitału z entuzjazmem przyjęli stwierdzenie liberałów, a potem neoliberałów, że wolność rynkowa polega na pozostawieniu gospodarki samej sobie, na sprowadzeniu roli państwa do funkcji stróża nocnego. „Wolność wedle neoliberalizmu to wolność lisa w kurniku. [W przeciwieństwie do tego] ordoliberalizm [w tym liberalizm społeczny] określa warunki ramowe gospodarki rynkowej, w których różnorodne podmioty, także te mniejsze, mają szansę na egzystencję na rynku, a nie stają się jedynie obiektem "pożeranym " przez większe"16. Dlatego też państwo ma według A. Rüstowa za zadanie uniemożliwiać zdobycie władzy nad rynkiem przez koncerny i monopole. W konsekwencji potrzeba silnego państwa, bowiem „tylko silne i niezależne państwo jest w stanie skutecznie zabezpieczyć funkcjonowanie wolnej gospodarki. Kiedy państwo jest słabe, to wtedy władzę nad rynkiem zdobywają grupy interesów,

15 A. Rüstow, Die Religion der Marktwirtschaft, Lit Verlag, Berlin 2009, s. 49.

16 S. Toennies, Die Liberale Kritik der Liberalismus, w: ibidem, s. 160. 
i to zarówno przedsiębiorcy, tworząc monopole i żądając subwencji, jak i robotnicy, tworząc syndykaty żądające jak najwięcej dla pracobiorców"17.

A. Rüstow twierdzi, że trzeba stworzyć nową wizję ustroju będącego trzecią drogą (Der dritte Weg), czyli ani za dużo, ani za mało państwa. Trzecia droga, jeśli chodzi o rolę państwa, polega na tym, że państwo ma być silne dla ochrony wolności gospodarczej obywateli, a nie - jak w przypadku państwa narodowego socjalizmu czy sowieckiego komunizmu - silne po to, aby zabrać wolność własnym obywatelom. Państwo tak jak przedsiębiorstwa prywatne ma bowiem tendencje do wpływania na działanie zasady konkurencji. Dlatego, aby ta zasada mogła funkcjonować, potrzebna jest jej ochrona.

A. Rüstow postulował wprowadzenie policji rynkowej. Państwo musi być sprawne, aby kształtować i wprowadzać system podatkowy w ten sposób, by w społeczeństwie rozwijały się MŚP, a z nimi ostoja demokracji - klasa średnia. Dzięki wprowadzeniu specjalnego podatku nierentowne będzie przekroczenie pewnego optimum wielkości firm i przedsiębiorstw ${ }^{18}$.

Zastanawiał się on również, jak stworzyć warunki do tego, by małe przedsiębiorstwa i drobni rolnicy mieli równe warunki startu i funkcjonowania, czyli takie, jakie mają ogromne firmy. Ważna jest również według niego reforma prawa patentowego. Polega ona na tym, że mniejsze firmy będą mogły korzystać z wynalazków, które są przez wiele lat zastrzeżone dla koncernów. To wszytko stanowi warunki, w których dobrze rozwijają się MŚP.

A. Rüstow obala też mit, że bezpośrednie kierowanie gospodarką przez państwo przyczyni się do wzrostu dobrobytu społecznego. Wskazuje przy tym, że zaprzeczyły temu próby wprowadzenia gospodarki planowej w Rosji Radzieckiej. Według niego powinno dochodzić do jak najmniejszej ingerencji państwa w życie gospodarcze, a jeśli jest ona potrzebna, to musi dotyczyć stwarzania warunków do równej walki wszystkich podmiotów gospodarczych, bez względu ma wielkość. A. Rüstow zaproponował zatem obiecującą pespektywę dla rozważań o miejscu i roli MŚP w gospodarce. Ukazał też warunki, dzięki którym mogą się one rozwijać na konkurencyjnym rynku.

\footnotetext{
17 A. Rüstow, op.cit., s. 36.

18 Ibidem, s. 57.
} 


\section{F. Zweig - polski liberalizm społeczny o problemach MŚP}

W Niemczech przedstawiciele ordoliberalizmu głosili i wciąż głoszą hasło wolnej konkurencji firm o różnej wielkości. W Polsce w leseferystycznym liberalizmie od początku transformacji obecne było hasło wolnego rynku. A jak było przed wojną? Czy wtedy tworzyły się podstawy do ujęcia przez liberalizm gospodarki w aspekcie ekonomiczno-społecznym, czyli w perspektywie, w której ukazuje się istota i rola MŚP?

Wśród bardzo ciekawych sporów toczonych w latach międzywojennych pomiędzy rodzimymi liberałami a etatystami warto przypomnieć dorobek zapomnianego i zignorowanego przez twórców rewitalizacji gospodarki rynkowej po $1989 \mathrm{r}$. F. Zweiga. Szczególnie dzisiaj, gdy słowo „neoliberalizm” dla większości brzmi złowrogo, jego wersja nowego liberalizmu nabiera wartości.

F. Zweig reprezentował młodszą generację liberałów krakowskich. Przyczynił się do wypracowania perspektywy umożliwiającej podjęcie właściwego dyskursu o MŚP. Zajmując stanowisko liberalne, upatrywał kluczową rolę MŚP w realizacji idei wolności gospodarczej. Według niego „niewątpliwie ideałem gospodarki typu liberalnego byłaby gospodarka indywidualna, jednostkowa, oparta na wyłącznej inicjatywie, ryzyku, przedsiębiorczości i kierownictwie właściciela warsztatu produkcyjnego, który za warsztat ten odpowiada własnym kapitałem i kieruje nim w należyty sposób" ${ }^{\prime 19}$.

Odzyskując język dla wypowiedzi o MŚP, podobnie jak ordoliberałowie wprowadza kategorię wolnej konkurencji i dodaje jeszcze kategorię rzeczywistej konkurencyjności w sensie zachowania działania zasady wolnej konkurencji rynkowej. F. Zweig już w początkowych fragmentach książki pisze: „WOLNA KONKURENCJA ODBYWAĆ SIĘ MOŻE TYLKO W WARUNKACH rzeczywistej KONKURENCYJNOŚCI, tj. w warunkach, w których szanse tej konkurencyjności są mniej lub więcej wyrównane. Wolna konkurencja w warunkach druzgoczącej przewagi - to tak jakbyśmy na ringu obok atlety postawili cherlaka i kazali im staczać boje w warunkach fair-play"20.

Ta metafora walki na ringu, jeśli ją rozwiniemy, ukazuje rolę państwa jako ustalającego reguły, według których toczy się gra rynkowa. Boks też potrzebuje sędziów nadzorujących przebieg gry i daje jednocześnie bokserom wolność w zadawaniu ciosów, ale ciosów zgodnych z regulaminem. Poza wszystkim by gra na ringu

${ }^{19}$ F. Zweig, Zmierz czy odrodzenie liberalizmu?, Oficyna Liberałów, Warszawa 1980, s. 165-166.

20 Ibidem, s. 21. 
i w gospodarce miała sens, muszą być jakoś ustalone kategorie wagowe, czyli muszą być zróżnicowane odniesienia państwa do podmiotów gospodarczych ze względu na ich wielkość i znaczenie dla społeczeństwa. Metafora boksu, a nie metafora wolnej amerykanki, jaką można by przywołać, gdy mamy do czynienia z kategorią wolnego rynku, w sposób rozsądny pokazuje miejsce i rolę MŚP, ale również rolę państwa. Państwo to nie bestia, którą najlepiej zagłodzić lub od której w momencie groźby bankructw pożycza się duże sumy, ale jest to aktywny uczestnik regulujący ramy gospodarki rynkowej. Jako takie nie może być ono słabe ani tanie. Urzędnicy muszą być dobrze opłacani, by nie mieli pokus działania na rzecz grup interesów gospodarczych.

F. Zweig broni możliwości kształtowania ram walki konkurencyjnej: „Panuje fałszywe mniemanie, że konkurencja wolna musi być konkurencją dziką. Tymczasem współzawodnictwo nie musi być wcale współzawodnictwem dzikim czy pierwotnym pozbawionym wszelkich elementów (regulacji). [...] to nie oznacza [zatem], by konkurencja miała występować w ramach całkowitej dowolności bezwzględnej abstynencji od wszelkich norm konwencji i współdziałania planowego [...]. Jak długo normy (regulacyjne) odpowiadają zasadom fair play, jak długo są dostępne dla wszystkich, nie można mieć nic przeciwko temu”"21. I dalej pisze: „To wszystko nie jest eliminowaniem konkurencji, ale konsekwentnym ustaleniem jej ram i porządku, co jest koniecznością dla współczesnego społeczeństwa, którego wymogi społeczne i kulturalne rosną. Porządkowanie konkurencji, stawianie jej pewnych wymogów społecznych, kulturalnych czy etycznych - nie jest likwidowaniem wolnej konkurencji, ale likwidowaniem konkurencji dzikiej - to nie jest to samo. Ujemne skutki konkurencji w zakresie załamań koniunkturalnych dadzą się także zmniejszyć celową polityką koniunkturalną [...], aktywizm koniunkturalny operujący metodami liberalnymi nie pozostaje w sprzeczności z założeniami sytemu liberalnego, nie eliminuje wolnej konkurencji, ale koryguje jej wybujałości, względnie dysproporcje"22.

Autor ten dopuszcza liberalną interwencję państwa. Twierdzi: „A znów liberał zgodzi się na interwencjonizm dla obrony czy przywrócenia zasady fair-play, zasady wolności przed atakami kartelowców, monopolistów czy koncesjonalistów"23. Dlatego F. Zweig był rzecznikiem ograniczenia ustawy monopolowej do niezbędnych w tamtych warunkach rozmiarów.

Ostatecznie można według F. Zweiga rolę interwencji państwa sprowadzić do „ingerowania w stosunki kartelowe, w okresie wielkich zatargów, państwo wkracza

\footnotetext{
${ }^{21}$ Ibidem, s. 231.

22 Ibidem.

23 Ibidem, s. 27.
} 
w stosunki pomiędzy pracą a kapitałem, przy występowaniu inflacji państwo chroni oszczędności, [państwo wkracza również] w przypadku nadużycia, eksploatacji czy uzyskania jednostronnej przewagi, gdy obcy kraj dumpinguje nasz przemysł, stwarzając warunki nielojalnej konkurencji - i tu interwencja jest konieczna, aby przywrócić warunki lojalnej konkurencji, gdy zasada słuszności i uczciwości, [czyli] zasady "uczciwej gry « zostały naruszone"24.

Z drugiej jednak strony trzeba uważać na skłonność instytucji państwa do zajmowania się gospodarką w niewłaściwy sposób. F. Zweig ostrzega: „W miarę jak państwo powiększa swe funkcje i zadania, w miarę jak państwo zajmuje się wszystkim, wszystko reglamentuje i kontroluje - rośnie jego budżet i nacisk fiskalny na obywateli”25.

Autor dostrzega też rolę organizacji przedsiębiorców w kontekście innych instytucji i czynników integrujących. „Dla rozwiązania wszelkich zadań technicznych, gospodarczych czy społecznych potrzeba: po pierwsze zrzeszania się, tworzenia organizacji, związków, zrzeszeń różnego typu, po drugie działania instytucji opartych na wartościach, po trzecie kultury w tym moralności i etyki" ${ }^{26}$. Za sprawą F. Zweiga dochodzi zatem - jak miało to miejsce w przypadku ordoliberałów - do przywrócenia podstaw dyskursu pozwalającego na przedstawienie problemów przedsiębiorców prowadzących MŚP.

Na koniec swych rozważań zawartych w książce Zmierz czy odrodzenie liberali$z m u$ ? F. Zweig podkreśla fakt, że „liberalizm buduje typ człowieka zdolnego do ryzyka i inicjatywy, w przeciwieństwie do człowieka ubezpieczonego, tj. obawiającego się ryzyka, szukającego wszędzie tylko zabezpieczenia, uciekającego przed ryzykiem, niezdolnego do inicjatywy. Liberalizm buduje typ przedsiębiorcy samodzielnego, pracującego we własnym imieniu i na własny rachunek, antyliberalizm typ człowieka zależnego, pracującego w imieniu i na rachunek zbiorowości, buduje typ człowieka tolerancyjnego, niefanatycznego, typ człowieka społecznego nastawionego na kompromis i współdziałanie [i jednocześnie] typ człowieka mocnego znającego swe prawa i obowiązki. Liberalizm stwarza legitymację moralną dla otwartego dążenia do zarobku, do poprawy bytu, do awansu społecznego w formie zwiększonego zysku czy zarobków, przez co ujawnia te głęboko zakorzenione potrzeby duszy ludzkiej, nadaje im otwartą legitymację moralną" ${ }^{27}$.

F. Zweig w latach dojścia nazistów do władzy w Niemczech ostrzega jednocześnie, że potrzeba wysiłku, by bronić liberalizmu: „Liberalizm jako system wolności może

\footnotetext{
24 Zob. ibidem, s. 26-29.

25 Ibidem, s. 199.

26 Ibidem, s. 223.

27 Ibidem, s. 274.
} 
rozwijać się tylko tam, gdzie istnieją warunki utrudniające nadużywanie tej wolności, jej przemianę w swawolę, chaos i anarchię. Liberalizm w warunkach niskiej kultury moralnej, niskiej oświaty, silnych namiętności rozkołysanych demagogią może dać pole ochlokracji, rządom instynktów, systemowi anarchii i chaosu [...]. Potrzeba jest pewnego minimum zdolności do samodyscypliny”28. Gdy zabraknie tych warunków, władzę gospodarczą przejmą koncerny, podporządkowując sobie w najlepszym przypadku MŚP lub je eliminując.

\section{Wnioski dotyczące budowy strategii promocji MŚP w świetle poglądów ordoliberalizmu i liberalizmu społecznego}

Ukazanie nie zawsze widocznych na pierwszy rzut oka problemów, z jakimi spotykają się osoby promujące MŚP, powinno stać się początkiem przemyślanej strategii wyrażania racji i interesów MŚP. Okazuje się, że nawet najlepiej sformułowane przekazy natrafiają na obojętność czy też ich rezultat jest daleki od oczekiwanego. Wiąże się to z uprzedzeniami, schematami pojęciowymi i ideologicznymi, w których trwa opinia publiczna i politycy. W niniejszym artykule zostały one ukazane i poddane krytyce. W dalszej części wskazano, że w tradycji niemieckiej myśli społecznej od dawna w sposób interesujący podejmowano temat MŚP. Wstępna analiza wykazała przede wszystkim przydatność obrony wolnej konkurencji i rozważań o roli MŚP w gospodarce rynkowej dokonanej przez ordoliberalizm i jego odmianę, czyli niemiecki liberalizm społeczny.

Następnie w niniejszej pracy odszukano zapomnianą rodzimą tradycję liberalizmu społecznego, broniącego już przed wojną racji MŚP. Wykorzystanie rozpatrywanych idei mogłoby być początkiem dalszych działań podjętych w celu przywrócenia znaczenia MŚP w życiu publicznym i na arenie politycznej. Chodzi mianowicie o to, że zapis konstytucyjny o społecznej gospodarce rynkowej daje szansę na wypełnienie go nową treścią w ten sposób, by podkreślał znaczenie MŚP dla gospodarki narodowej. W tym celu potrzebna jest praca w kierunku nowego, zgodnego z duchem polskim określenia koncepcji społecznej gospodarki rynkowej na podstawie doświadczenia związanego z funkcjonowaniem ordoliberalizmu i liberalizmu społecznego. Kiedy się tego dokona, można będzie podjąć się próby przekonania środowisk opi-

28 Ibidem, s. 281. 
niotwórczych i polityków do tej idei, a następnie domagać się realizacji postulatów, jakie wypływają z nowego ujęcia koncepcji społecznej gospodarki rynkowej.

Powróćmy na koniec podsumowania do obserwacji K. Darwina i wyciągnijmy na ich podstawie wnioski dotyczące samej gospodarki. K. Darwin zauważa, że „wiele faktów w naturze przekonuje nas o słuszności zasady, że największą bujność życia można osiągnąć drogą wielkiego zróżnicowania budowy. Na bardzo małych terenach, zwłaszcza otwartych dla imigracji obcych form, gdzie walka pomiędzy jednym osobnikiem a drugim musi być bardzo ostra, znajdujemy zawsze wielką rozmaitość mieszkańców. Na przykład na kawałku darni trzy stopy długim i cztery szerokim, wystawionym w ciągu wielu lat na zupełnie jednakowe warunki, znalazłem dwadzieścia gatunków roślin, które należały do osiemnastu rodzajów i ośmiu rzędów, co dowodzi, jak znacznie rośliny te różniły się od siebie. To samo widzimy u roślin i owadów na małych, jednostajnych wysepkach, równie jak i w małych zbiornikach słodkowodnych"29. Wprowadzając analogię pomiędzy rozwojem świata organicznego a rozwojem gospodarczym, możemy ostatecznie stwierdzić, że istnienie MŚP, tak zróżnicowanych tworów gospodarczych, nie stwarza problemów dla państwa, społeczeństwa i gospodarki, a przeciwnie - zachowuje ich witalny charakter. Tym samym ordoliberalizm i liberalizm społeczny A. Rüstowa i F. Zweiga zdaje się propagować działanie prawa różnorodności na polu gospodarki.

\section{Small and medium entrepreneurship in liberalism and social liberalism}

The paper was inspired by a debate between entrepreneurs and social scientists on the problem of promotion of local SMEs. In this context, the aim of the paper is to demonstrate why such a promotion is not successful. Moreover, in the paper I attempt to form a critique of the ideologies that disregard SMEs (Darwinism, Marxism and neoliberalism) and to present two liberal ideologies alternative to neoliberalism: ordoliberalism and social liberalism, which may constitute a good starting point for bringing back the importance of SMEs into public life.

Keywords: SME, liberalism, A. Rüstow, F. Zweig, social market economy

\footnotetext{
${ }^{29}$ K. Darwin, O powstawaniu gatunków droga doboru naturalnego, PWRiL, Warszawa 1959-1960, http:// www.wiw.pl/Biologia/Ewolucjonizm/TeoriaEwolucji/Esej.asp?base $=r \& c p=10 \& c e=1$.
} 


\section{Les petites et moyennes entreprises dans l'ordo-libéralisme et le social- -libéralisme}

Larticle a été inspiré par une discussion entre les entrepreneurs et les chercheurs en sciences sociales sur le problème de la promotion des PME nationales. Dans ce contexte, l'article montre pourquoi cette promotion donne des résultats médiocres. Lauteur tente de critiquer les idéologies qui marginalisent l'importance des PME (le darwinisme, le marxisme, le néo-libéralisme). Ensuite, il tente de montrer les deux traditions libérales alternatives au néolibéralisme - l'ordo-libéralisme et le libéralisme social. Selon l'auteur, elles peuvent être une bonne base pour restaurer l'importance des PME dans la vie publique.

Mots-clés: PME, le libéralisme, A. Rustow, F. Zweig, léconomie sociale de marché

\section{Малое и средние предпринимательство в концепции либерализма и социального либерализма}

Источником вдохновения для написания статьи стала дискуссия между предпринимателями и представителями общественных наук по вопросу поощрения деятельности национальных МСП. В этом контексте, исследование показывает, почему такая деятельность не является успешной. Автор подвергает критике идеологии недооценивающие значение малого и среднего бизнеса (дарвинизм, марксизм и неолиберализм) и представляет в качестве альтернативы неолиберализму две либеральные идеологии: ордолиберализм и социальный либерализм, которые могут стать хорошей отправной точкой для восстановления значимости МСП в общественной жизни.

Ключевые слова: МСП, либерализм, А. Рюстов, Ф. Цвейг, социальная рыночная экономика 